\title{
TEACHING ENGLISH "BUILDING UP BASIC GRAMMAR" TO THE CHILDREN OF MALASILEN COUNTRY, NORTH SORONG DISTRICT, SORONG CITY
}

\author{
Agustinus L. Masan \\ Program Studi Bahasa Inggris, Universitas Victory Sorong \\ email: liamasanagusto@gmail.com
}

\begin{abstract}
ABSTRAK
Bahasa Inggris tak akan jauh pergi dari basic grammar karena basic grammarlah yang membantu pemula dalam memahami hal-hal besar dalam Bahasa Inggris. Dia adalah dasar dari pemahaman. Anak-anak SD dan SMP di negeri ini sudah belajar bahasa inggris sejak dini tapi apakah pemahaman yang otentik dari mereka juga terbangun? Sistem pendidikan menjadi problem utama untuk membangunkan karakter belajar anak-anak zaman ini. Metode yang digunakan dalam kegiatan pengabdian pada masyarakat ini adalah pengajaran Bahasa Inggris. Tahapan pengajaran terdiri dari studi pendahuluan, pemaparan materi, dan evaluasi. Kegiatan pengajaran Bahasa Inggris "building up basic grammar" ditujukan kepada khalayak sasaran.Tingkat keberhasilan pengajaran ini ditentukan oleh adanya perbedaan pemahaman dan pengetahuan mengenai basic grammar yang belum baik dengan sesudah pelaksanaan pengajaran, dimana adanya pemahaman dan pengetahuan yang lebih efektif dan memadai.
\end{abstract}

Kata kunci: Basic Grammar,To Be, Personal Pronoun, Nominal Sentence, Verb Sentence.

\begin{abstract}
English will not leave behind the basic grammar because of basic grammar, which helps the beginner for understanding the bigger case in English. It is as the foundation of understanding. Children of elementary school and junior high school in this country have learned English early but did it build their authentic understanding? The education system becomes the main causative problem for building the children character learning of this era. The method used in this serving society action is teaching English. Teaching stage consists of: the previous study, presenting the material, and evaluating. English teaching action "building up basic grammar" is to the public concern. The level of success in this teaching disposed of by there is a distinction between understanding and knowledge toward basic grammar before and after teaching, where there is an effective and a well understanding and knowledge.
\end{abstract}

Keyword: Basic grammar, To Be, Personal Pronoun, Nominal Sentence, Verb Sentence. 


\section{INTRODUCTION}

Learning English is the first global tool which needs to be known and need to be dug for a deep understanding of it. It is very important for us to communicate with people all around the world. Nowadays, English has taught at every level of schools. Even in Sorong city, English has taught to the students of playgroup. In reality, specifically Indonesia, there are so many people who can not speak English well even if they have learned it for more than years. It is also a boomerang because it is as a foreign language.

English is very needed by the students, so the English teacher should take attention toward the students' competent primary the four basic skills: speaking, writing, reading, and listening. This is also important for the English teacher to promote and motivate the students to love learning and love English. Today, English teacher still felt difficult in how to choose the technique and media used and how to teach well. In this case, teachers have a responsibility to lead the students during their learning process and remind them of learning hard and harder. For this situation, our team personally make a closer distance to the society by using my method. Learning English is important but do not push them (the students) for a long time, and more words memorizing is not accurate because today's children are a friend of Smartphone era. They are busy with it. English teachers have to find a personal problem nowadays than finding and choosing our real way of teaching.

We realize, or this serving society team saw and felt the need for motivating the children to avoid the misunderstanding during communication in English. In the other hand, remind them of-of the basic differences of a nominal sentence or affirmative sentence and verb sentence. This is important to be learned detail, so the children from formal and informal schools become usual and enjoy learning English. Children from Malasilen country, district of north Sorong, Sorong City, TPU street, KM 10 is chosen by the team as the representative children of Sorong City. This serving society is hoped will be done in another place also. Bringing the basic need for learning English and a better understanding of it is our team's motto.

Serving society team come back to realize also that basic grammar is the primary term and or as the first item to when tend to learn English. In the other side, we are allowing students or children to take part in the teaching and learning process. Here we are trying to explain the case simply, well, and slowly in other to make it easier for the children to understand. This way, the children will distinguish the classic error, namely 
wrong in placing subject and (auxiliary verb) To me, wrong in differing between nominal sentence and verb sentence. Children sometimes put the auxiliary verb to be in verb sentence and on the contrary. The reason why, the serving to the society here with a given title "Teaching English "Building Up Basic Grammar To The Children of Malaysian country, TPU street Sorong city."

\section{FORMULATION OF THE PROBLEM}

According to the interview making to the students from elementary and junior high school from our group learning, it can be concluded that understanding about basic grammar is so poor or limited. This happened because schools are just focusing on following what is saying by the leading government. So, here are some questions as the formulation of the problem. They are as follow:

a. Did the schools teach the students about basic grammar or on the contrary?

b. How to expand the understanding and to reduce the misunderstanding of students against teaching English specifically about basic grammar?

\section{METHODOLOGY}

The method is used in this serving the society is public education method. The method used here is to build up understanding and knowledge to the public society, specifically the children while stages for doing this serving the society in Malasilen country are as follow:

\subsection{Pre-Activity (Pre-Interview)}

For the first place, before doing the teaching, our team has an interview against the problem of basic grammar at school and the way out as the solution. As to the interview finding, it can be concluded that understanding the case is too poor or very low. That is why our team have to do this teaching the material about building up basic grammar in Malasilen country.

\subsection{Main Activity}

There are the material stages which are presented in this serving the society about building up the basic grammar to the children of Malaysian country. They are as follow:
a. To Be,
b. Personal Pronoun,
c. The nominal sentence, and 
d. Verb sentence

There is also a schedule of the activity about teaching English building up basic grammar. The schedule is as below:

\begin{tabular}{|c|l|c|}
\hline Hari/Tanggal & Jam & Kegiatan \\
\hline Friday, May 2 $2^{\text {nd }}, 2018$ & $08.00-08.30$ & Member Registration \\
\cline { 2 - 3 } & $08.30-09.30$ & Pre-interview \\
\cline { 2 - 3 } & $09.30-12.00$ & Teaching Material \\
\cline { 2 - 3 } & $12.00-13.00$ & Break Time \\
\cline { 2 - 3 } & $13.00-15.00$ & Post-interview \\
\cline { 2 - 3 } & $15.00-$ finish & Closing \\
\hline
\end{tabular}

\subsection{Post Activity (Post-Interview)}

There is also a technique were used to measure how far children's understanding and knowledge about basic grammar; we called a post-interview. This step is the way to compare with pre interview after getting the material presentation. As to the comparison between preinterview and after getting the material presentation, so can be known how far the children's understanding and knowledge about basic grammar.

\section{FINDINGS AND DISCUSSION}

Teaching against the children in kelurahan Malasile about building up basic English can be done in some stages. They are as follow:

\subsection{Auxiliary Verb "To Be"}

According to Oxford Advanced, Learner's Dictionary states auxiliary verb such as be, do and have used with main verbs to show tense, aspect, voice, mood, and person. Here our concern is in person.

\subsubsection{Present Simple}

Am

Is

Are

\subsubsection{Simple Past}

Was

Were 


\subsection{Personal Pronoun}

4.2.1 Decline of Personal Pronoun

\begin{tabular}{|l|l|l|l|}
\hline As subject & As object & \multicolumn{1}{|c|}{$\begin{array}{c}\text { As Possessive pronoun or } \\
\text { possessive determiner }\end{array}$} & \multicolumn{1}{|c|}{ As reflexive pronoun } \\
\hline I & Me & My & Mine \\
You & You & You & Yours \\
He & Him & His & His \\
She & Her & Hers & Hers \\
It & It & Its & Its \\
We & Us & Our & Ours \\
They & Them & Their & Theirs \\
\hline
\end{tabular}

4.2.2 Languages typically have personal pronouns for each of the three grammatical persons:

First-person pronouns normally refer to the speaker, in the case of the singular (as the English I), or the speaker and others, in the case of the plural (as the English we).

Second-person pronouns normally refer to the person or persons being addressed (as the English you); in the plural, they may also refer to the person or persons being addressed together with third parties.

Third-person pronouns normally refer to third parties other than the speaker or the person being addressed (like the English he, she, it, they).

4.2.3 Personal Pronoun and To Be

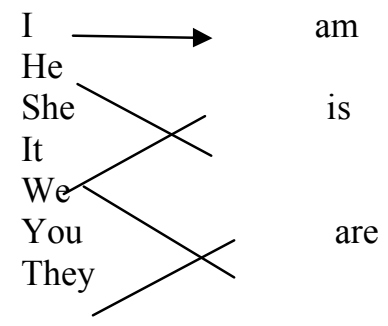

\subsection{Nominal Sentence}

Nominal Sentence is the sentence which the predicate is not (Verb), but consist of Noun (kata benda), Adjective (kata sifat) atau Adverb (kata keterangan).

In Nominal Sentence, between subject and predicate should be put "to be" which proper to the subject of a sentence in other to change the verb.

Examples:

- I am a lawyer. (Noun)(Saya Adalah Seorang pengacara) 
- He is very clever. (Adjective)(Dia Sangat panda)

- She is at my house. (Adverb)

(Dia ada di rumahku)

\subsection{Verb Sentence}

In English, each sentence must have (verb). Verb may in Infinite, Past Tense atau Past Participle, for example: to write-write-wrote-written (menulis), to say-say-said-said (berbicara), to eat-eat-ate-eaten (makan), etc. if the sentence has no verb, so it can use the Auxiliary Verb to be, namely: am, is, are, was, and were.

Verbal Sentence is a sentence which the predicate is (Verb).

Examples:

She goes to the market.(Dia pergi like Pasar)

I read the newspaper every morning.(Saya membaca koran setup page)

Notes:

1. In Affirmative Sentence:

- Subject I, you, we, they its verb without adding $s / e s$.

- A subject he, she, it its verb adding $s / e s$.

2. For Negative Sentence is used auxiliary verb does/do/did" and adding "not" dengan ketentuan:

- Subject $I$, you, we, they should with auxiliary verb do not (don't).

- A subject he, she, it should with auxiliary verb does not (doesn't).

- While auxiliary verb did not (didn't) is used for all the subject in simple past.

- This auxiliary verb is placed after the subject.

- If there an auxiliary verb like can, shall, will, and so on in a sentence just put not.

3. For making Interrogative Sentence is also used an auxiliary verb "does/do/did"with some reasons:

- Do is used for the subject I, you, we, they.

- Does, is used for the subject he, she, it.

- Did is used for all subjects.

- This auxiliary verb is placed in front of the sentence.

- If there is an auxiliary verb like can, shall, will, and so on just placing it in the beginning. 
- Question which begin with the auxiliary verb "do/does/ did" can be responded by "Yes" or "No."
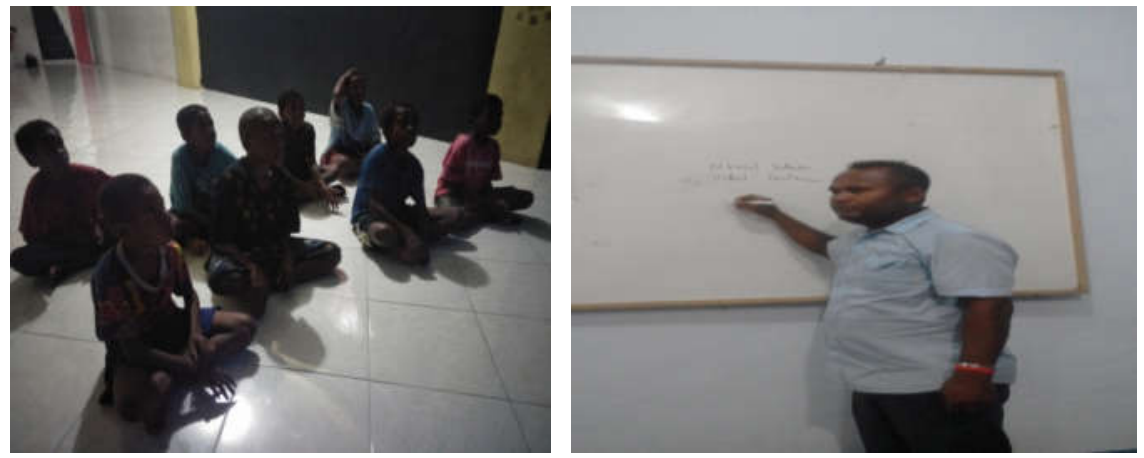

Gambar 1. The situation during the teaching

\section{CONCLUSION}

After findings in this activity of teaching children, our serving to the society team can conclude that children from a different economic background and education background are thrilled and satisfy with our building up primary grammar teaching. Why they were filled Mengapa puas dan sensing Karena selama belajar Bahasa Inggris mengenai basic grammar penjelasannya simple dan detail. They were also satisfied because the differences between the nominal sentence and verb sentence never explained well and gave full attention about this, so the students did not understand at school. In other words, teachers at school did not provide a particular time for the students to understand it. Our team gave a special explanation and time for the children so they got the main point of basic grammar and misunderstanding can be reduced during communication in English of the children. In another side, this is very affected by the children's interest against basic grammar and minimize the errors. So as final words for this serving to the society is expecting and struggling in other the activity like this can be done for the future or on going. 


\section{BIBLIOGRAPHY}

Greenbaum, Sidney, dkk. (1990). Student's Grammar of The English Language. England: Pearson Education Limited

Habeeb, F. S, dkk. (1994). Everyday Antonyms and Synonyms. Jakarta: Bhuana Ilmu Populer Azar, Schrimsher, Betty. (1990). Fundamental of English Grammar.Indonesia: Binapura Murphy. (1998). English Grammar in Use. United Kingdom: Cambridge University Press Sasian, Finne.(2010). Kamus Smart. Jakarta: Bintang Indonesia

Hornby, S. A. Eight Edition. (2010). Oxford Advanced Learner's Dictionary. New York: Oxford University Press

Richards, C. Jack, dkk. (1992). Longman Dictionary. United Kingdom: Longman Group UK Limited 